\title{
Effects of Inventory Warehousing Systems on the Financial Performance of Seventh Day Adventist Institutions: A Case of Adventist Book Centers (ABC), Kenya
}

\author{
Boniface John Wambua ${ }^{1}$, Walter B. Okibo ${ }^{1}$, Andrew Nyang' ${ }^{\prime} u^{2} \&$ Sixtus Momanyi Ondieki ${ }^{1}$ \\ ${ }^{1}$ Department of Commerce and Economic Studies in the College of Human Resource Development, Jomo \\ Kenyatta University of Agriculture and Technology, Kenya \\ ${ }^{2}$ Department of Business Management, Marist International University College (A Constituent College of \\ Catholic University of Eastern Africa), Nairobi, Kenya \\ Correspondence: Sixtus Momanyi Ondieki, Department of Commerce and Economic Studies in the College of \\ Human Resource Development, Jomo Kenyatta University of Agriculture and Technology, P.O Box 4384-40200 \\ Kisii, Kenya. E-mail: sixtuso2001@yahoo.com
}

Received: February 9, 2015

doi:10.5539/ijbm.v10n4p259
Accepted: March 25, 2015

Online Published: March 27, 2015

URL: http://dx.doi.org/10.5539/ijbm.v10n4p259

\begin{abstract}
Effective Inventory management and control systems are critical to the profitability and overall performance of many companies. Many Adventist Institutions have trouble resulting from operating losses and cash flow problems. This could be because of low income, poor management of inventory systems, and lack of financial discipline. The aim of this study was to investigate the effects of the management of warehousing inventory systems on Seventh day Adventist institution's financial performance in Kenya. The main objective is to evaluate the effects of inventory warehousing systems on Seventh Day Adventist Institution's financial performance of. The specific objective that guided this research was to assess the effect of Inventory warehousing systems on the financial performance of Adventist Book Centers. The researcher used descriptive research design in undertaking this study. The target population was 216 employees at HHES while sample size was $30 \%$ of the target population totaling to 64 employees. The sampling design adopted was be stratified random sampling because population is heterogeneous. Data was analyzed by use of statistical package for social science (SPSS) regression and correlation. Data was then presented using tables and figures. The empirical results revealed a positive significant relationship between financial performance and Inventory warehousing systems at 0.05 significance level. Further, they showed that Inventory warehousing systems had a significant effect on performance with a beta coefficient of 0.311 . The study suggests that owners/managers of $A B C$ embrace effective inventory warehousing systems as a tactic to further their financial performance and in overall performance of their organization.
\end{abstract}

Keywords: general conference auditing service (GCAS), inventories, inventory management system, procurement inventory management system

\section{Introduction}

Inventory management systems curb the challenge of productive inventory management to support an upward trend in sales while keeping the investment cost at the lowest level consistent with adequate customer service (Ellram, 1996). Management of inventory typically represents $45-90 \%$ of all expenses for business and is therefore needed to ensure that the business has the right goods at hand to avoid stock-outs, shrinkage (spoilage/theft), and to provide proper accounting (Khan, 2007). According to Gerald (2006), inventory management systems are processes of managing inventory in order to meet customers needs by maintaining the lowest possible cost of investment.

Preliminary aspect in the inventory management process is determining the cost of carrying inventory. These costs include, among others, storage cost, inventory risk, and loss of opportunity cost of capital. Inventory management as an important aspect in helping to ensure that ordering, manufacturing, ware housing and distribution is successful, is evident. The effectiveness of inventory management system, is directly measurable by how successful a company is in providing high levels of customer service, low inventory investments, 
maximum profits and low costs of inventory (Ansari, 2009).

In the modern world, organizations aim to achieve effectiveness, efficiency, and economies of scale and this necessitates holding of inventory. This however poses a great challenge to institutions. The how must to be invested in inventories and that constitutes right inventory levels remains a challenge to many firms. Firms have turned to the use of modern technology as a remedy (Waller, 2009).

In Kenya, vendor Managed Inventory systems (VMIS) strive towards closer cooperation between the members of supply chain. Vendor Managed Inventory/Consignment Stock is inventory that is in the possession of the buyer (shop, warehouse or store), but is still owned by the supplier. Payment of the inventory is made once it is sold. (Kumar, 2009). Lee (2009) found that VMI greatly reduced inventory-carrying costs and stock out problems while, at the same time, it offered the ability to synchronize both inventory and transportation decisions.

Inventory management systems has two components namely; inventory monitoring systems and inventory information management systems, and this has been a neglected area as far as financial management is concerned in SDA institutions. More emphasis has been given on stewardship, more giving by members, issues on budgeting, etc. The church institutions include Home health education service, (HHES), which is concerned with publishing, hospitals, printing houses, service organizations, Guest houses, teachers training Colleges and schools. These Institutions face challenges in the management of inventory. In many audit reports by GCAS (General Conference Auditing Services), inventory management has been cited as an area that has a lot of deficiencies. Little attention is given on the impact inventory management system has on the overall financial performance of the institutions (Lizardo, 2009). In this study the researcher will concentrate on this institution (HHES) and specifically the Adventist book centres (ABCS) which are bookshops managed by this Adventist institution to determine the effects of Inventory warehousing systems on the financial performance of Seventh Day Adventist Institutions.

\subsection{Statement of the Problem}

Many business organizations spend a lot of resources installing inventory management systems with the aim of minimizing their total operating costs, and enhance service delivery to customers. Globally the SDA church has invested in such systems expecting to achieve the aforementioned results in its denominational operations and in the financial and business institutions sponsored by the denomination (Meyer, 2010).

However, many audits done by the General Conference Auditing Services of the Seventh-day Adventist Church reveal that there is an increased level of discrepancies in the manner in which the inventory management systems are harmonized. On a number of occasions, there are cases of misstatements and inaccurate and fraudulent records detected within the system. Many SDA Institutions within East African Union (EAU) have trouble resulting from operating losses and cash flow problems. Quite often, piles of obsolete stock are seen within the premises of these institutions, resulting in huge write offs eating into the bottom line of these institutions. Many a times, stock outs are also experienced resulting in high customer turnover and therefore low sales and poor service delivery to customers. Inventory management normally becomes reportable issues (condition) and is always raised in the management letters to many institutions where very little attention is given in the management of inventories as records are inadequate (Lizardo, 2009)

This study will therefore sought to evaluate the effects of Inventory warehousing systems on the financial performance of Seventh Day Adventist Institutions and make recommendations on the areas that require improvement for effective and efficient inventory management.

\section{Related Literature Review}

A Well implemented warehousing system helps in coordinating operations in the stores. This is imperative in ensuring smoothing of production and this benefits the organization from the economies of scale and improved customer service. Well implemented warehousing systems are designed to help in the specification of inventory procedures, operation and control. An inventory warehousing system is primarily concerned with proper material handling and safeguarding of inventory specifically designed for side loading in small quantities (Ronald 2009). Vendor Managed Inventory systems (VMIS) strive towards closer cooperation between the members of supply chains in the area of inventory and demand management Vendor Managed Inventory is an inventory management process that falls under the 'push' stock management processes and as such, Kor (2008) argues that these are processes are triggered by interpretation of an expected demand. Vendor Managed Inventory/Consignment Stock is inventory that is in the possession of the buyer (shop, warehouse or store), but is still owned by the supplier whose payment is done once sold (Likert, 2010). 
The VMI initiative has the goal of accomplishing deeper integration and collaboration between the members of the supply chain in order to cope with the ever decreasing time windows for product and service fulfillment in order to improve operational efficiency. If a company's Procurement \& Logistics Department is successful, the company will have better chances of surviving. This can be best illustrated in retail chain firms that have to deal with multiple suppliers and large volume of inventory hence storage burden is distributed between the supply and the buyer (Angulo, 2009).

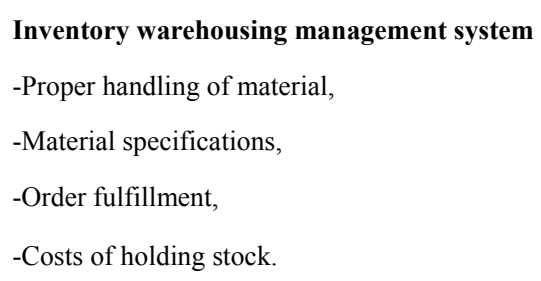

Figure 1. Conceptual framework

This conceptual framework will be based on effects of inventory warehousing systems on the financial performance of seventh day Adventist institutions. The parameter under which financial performance will be examined will be on the basis of profitability.

\section{Materials and Methods}

This study employed a descriptive research design. The study targeted staff in finance and procurement departments in the Adventist Book Centers across the country. The target population of this research study was 216 members of staff. The study relied on both primary and secondary data obtained from ABC staff. The instruments used were questionnaires. Respondents' opinions were quantified by rating them on a five point scale. Data was analyzed using mean, standard deviation, frequency tables, percentages, and Pearson correlation and regression analysis.

\section{Findings}

Respondents were asked about the effect of inventory warehousing management systems on financial performance of $\mathrm{ABC}$ centres in Kenya. Results were indicated in the chart below.

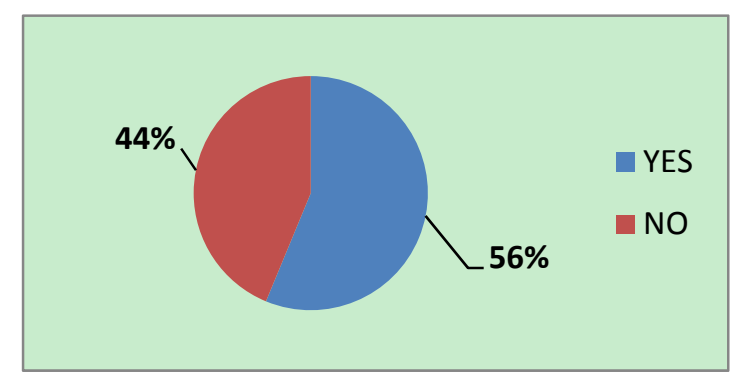

Figure 2. Effects of inventory warehousing systems on financial performance

Source: Research data (2014).

Majority of the respondents (56\%) indicated that warehousing management systems had an effect on financial performance. Further analysis on the extent inventory warehousing management systems affected financial performance was illustrated in the table below. 
Table 1. Analysis of inventory warehousing management systems parameters on financial performance

\begin{tabular}{lll}
\hline Extent & Frequency & Percentage \\
\hline To a very large extent & 20 & 20.8 \\
To a large extent & 48 & 50 \\
To a moderate extent & 22 & 23 \\
Less extent & 4 & 4.1 \\
No extent & 2 & 2.1 \\
Total & 96 & 100 \\
\hline
\end{tabular}

Results in Table 1 indicates that inventory warehousing management systems affected financial performance to a large extent as indicated by majority $50 \%$. This means that warehousing is critical to management of inventory as to maintain efficiency in stock handling and effective costs reductions. Areas of application of inventory warehousing management systems, as indicated by the respondents included parameters such as proper handling of material, material specifications, order fulfillment, costs of holding stock and cost effectiveness were deduced to ascertain how they affected financial performance. On a Likert scale to determine the respondent's opinion on the level of agreement with the parameters mentioned, the findings were illustrated in the table below.

On the basis of the above table, the weighted average score is calculated

Weighted average $=\sum \mathrm{f}(\mathrm{n}) / \mathrm{N}$

Table 2. Analysis of inventory warehousing management systems parameters on financial performance

\begin{tabular}{lllllll}
\hline Inventory warehousing indicators & 1 & 2 & 3 & 4 & 5 & Weighted averages \\
\hline Proper material handling & 5 & 7 & 18 & 41 & 25 & 3.63 \\
Material specifications & 7 & 16 & 23 & 38 & 12 & 3.14 \\
Order fulfillment & 21 & 19 & 33 & 17 & 6 & 2.23 \\
Cost of holding stock & 12 & 25 & 28 & 25 & 6 & 2.51 \\
Cost effectiveness & 43 & 23 & 13 & 15 & 2 & 1.74 \\
\hline
\end{tabular}

The results indicate the effects of inventory warehousing management systems on financial performance. The findings shows that most respondents agreed that proper handling of materials was cost-effective on inventory warehousing management systems thus affecting financial performance of the institutions with a weighted average of 3.63 .

Respondents also agreed that with the inventory systems, they were more effective in determining material specifications, as confirmed by a weighted Likert average of 3.14. Respondents moderately agreed that inventory practices aimed at ensuring cost of holding stock was minimum this was experienced every time inventory management systems were used. This was evidenced by a weighted average of 2.51 . The respondents moderately agreed that order fulfillment affected financial performance and had low weighted average at 2.23. This implied that organization scored just fairly when determining the timing of order replenishments. This meant that they were not able to fulfill orders because the levels of their orders were not dependent on the lead-time. The outcome of the study also indicated that respondents strongly agreed that inventory warehousing management systems were effective in controlling and maintaining cost at the lowest levels possible. This scored a low weighted average of 1.74. This agrees that many organizations are not keen in using integrated systems to manage warehouses in order to reduce costs hence maximizing profits of the organization. In environments that thrive on lead-time, such inventory systems would be a necessity.

Analysis of Variance (ANOVA) was carried by the study to test the relationship between the variables and how significant they are to financial performance of the firm. The table below indicate the findings.

Table 3. Summary ANOVA ( $\mathbf{N}=\mathbf{9 6})$

\begin{tabular}{llllll}
\hline & Sum of squares & Df & Mean square & F & Sig \\
\hline Regression & 1223.326 & 4 & 375.432 & 65.463 & .000 \\
Residual & 456.760 & 68 & 7.875 & & \\
Total & $\mathbf{1 6 8 0 . 0 8 6}$ & $\mathbf{7 2}$ & & & \\
\hline
\end{tabular}


Table 3 shows the F-Statistic which indicate that there is a statistically significant relationship between financial performance and the set of predictor variables: b1x1, b2x2, b3x3 and b4x4, $(F(4,68)=65.463, p<0.05)$. This means that the four-predictor variables as a whole were contributing to the variation in financial performance.

\section{Summary}

From the findings, it was found that all departments engage so much in inventory management systems as a way of improving their financial performance. It was discovered that constructs of inventory management systems such as inventory systems applied had affected financial performance of Adventist Book Centers to a very large extent. It was also found that the inventory systems had applied directly to volume of sales thus increasing the profits of the firm. Further results show that inventory warehousing management systems was directly influencing financial performance. However, proper handling of material was much accrued to inventory warehousing management systems to ensure quality and cost reduction so that material obsolesce is avoided at all costs.

Hence, we can conclude that inventory warehousing systems is critical to the success of any organization intending to improve their sales. The effectiveness of inventory management is found in its capacity to hold an appropriate amount of inventory so as to avoid damage, spoilage, and loss. According to Dimitrios (2008), prudent inventory management requires the analysis of the costs of maintaining certain levels of inventory. This is in order to avoid excess or holding too little inventory that may either way lead to high costs. Its therefore prudent to ensure an effective stock management system capable of forecasting future sales (Atrill, 2006).

Respondents agreed that warehousing management systems affected financial performance to a large extent. However, findings were deduced on such inventory warehousing management systems parameters as proper material handling, material specifications, order fulfillment, cost of holding stock and cost effectiveness. Findings, reveal that majority of respondents agreed that proper material handling was one major parameter that inventory warehousing management systems was accrued to and thus affected financial performance.

Therefore evaluating the correlation between inventory management systems and inventory costs showed a positive effect on the performance of the businesses. This was seen to have a significant effect on the financial performance

\section{Conclusion}

According to findings, $56 \%$ agreed that inventory warehousing management affected financial performance of $\mathrm{ABC}$ and to a large extent. Warehousing management is critical to any organization dealing with inventory and any challenge on the department is a blow to financial performance due to low sales. It was clear that respondents agreed that proper handling of material was mostly accrued to inventory warehousing management systems compared to other parameters such as order fulfillment, cost of holding stock, material specifications and cost effectiveness. Therefore, proper material handling facilitates the delivery of goods, works, and services. A good warehousing management will integrate their systems to ensure efficiency in holding stock and effectiveness in cost reduction. This should be the motivation behind the implementation of inventory management systems to ensure efficiency that will eventually lead to the realization of the objectives of the seventh day Adventist institutions.

\section{Recommendation}

There is need to integrate warehousing management systems in order to manage inventory within organizations. Integration of warehouse should include utilization of such as Barcoding, Auto ID data Capture (AIDC) technology to efficiently monitor flow of inventory. Consequently, the benefits of proper inventory management systems will be realized. This will also ensure proper material handling, order fulfillment and cost effectiveness and costs of holding stocks are well established. Technology is essential for any organization changes, warehouse managers, or the Supply chain management should identify the role of vendors as critical success factor. The Seventh Day Adventist Book Centers staff should undergo training in management Information Systems so that they can be able to utilize the systems with easy. The management of Seventh Day Adventist Book Centers should invest on research to find out the best and suiting systems that can fit well with their institutions considering the cost effects and adaptability.

\section{References}

Angulo, A. N. (2009). Supply Chain Information sharing in a vendor managed inventory partnership. Journal of Business Logistics, 25(1), 101-120. 
Fox, M. L. (1996). Integrating vendor-managed inventory to supply chain decision-making. Conference Paper, APICS 39th International Conference. New York.

Gerald, C. (2006). Purchasing \& Supply Management (4th ed.). Pearson Publishers.

Handfield, R. (2009). Reducing costs across the supply chain. The Journal for Quality and Participation. Cincinnati, 21(2), 54-60.

Kor, Y. A. (2008). Contributions to the Resource-based view of Strategic Management. Journal of Management Studies, $\quad 41(1), \quad 22-23 . \quad$ Retrieved from http://onlinelibrary.wiley.com/doi/10.1111/j.1467-6486.2004.00426.x/pdf

Likert. (2010). The New Patterns of Management. NewYork: McGraw-Hill.

Lizardo, J. (2009). International Control on Organizational assets. KIsumu, Kenya: East Africa Union Internal Control Seminor.

Meyer, H. (2010). An eight-step approach to inventory accuracy: A case study at Leviton manufacturing company. Production and Inventory Management Journal, 32, 40-42.

Waller, M. J. (2009). Vendor-Managed Inventory in the retail chain. Journal of Business Logistics, 20(1), 183-203.

\section{Copyrights}

Copyright for this article is retained by the author(s), with first publication rights granted to the journal.

This is an open-access article distributed under the terms and conditions of the Creative Commons Attribution license (http://creativecommons.org/licenses/by/3.0/). 